\title{
Pengaruh Pengembangan Terhadap Kinerja Pegawai Pada Kantor Inspektorat Kabupaten Mandailing Natal
}

\author{
Muhammad Isa, S.T., M.M
}

Institut Agama Islam Negeri Padangsidimpuan

misastmm@gmail.com

\section{Bungkus Adek Irawan, S.E.}

Institut Agama Islam Negeri Padangsidimpuan

\begin{abstract}
Abstrak Penelitian ini bertujuan untuk mengetahui pengaruh pengembangan sumber daya manusia (pegawai) terhadap kinerja pegawai pada Kantor Inspektorat Kabupaten Mandailing Natal. Penelitian ini dilakukan mengingat peran penting pegawai dalam pencapaian tujuan sebuah organisasi. Oleh karena itu usaha peningkatan kinerja pegawai penting untuk dilaksanakan, salah satunya melalui pengembangan sumber daya manusia melalui pendidikan dan pelatihan.

Penelitian ini adalah penelitian kuantitatif dengan teknik regresi linear sederhana. Pengumpulan data menggunakan angket yang disebar kepada 43 orang responden. Pengolahan data dilakukan dengan bantuan software SPSS.

Dari penelitian yang telah dilakukan disimpulkan bahwa ada pengaruh positif pengembangan sumber daya manusia terhadap kinerja pegawai pada Kantor Inspektorat Kabupaten Mandailing Natal. Adapun kontribusi pengembangan sumber daya manusia terhadap kinerja pegawai adalah sebesar $15,3 \%$ sedangkan sisanya $84,7 \%$ dipengaruhi oleh variabel lain yang tidak diteliti dalam penelitian ini. Persamaan regresi yang diperoleh adalah Kinerja Pegawai $=55,873+$ 0,324(Pengembangan Sumber Daya Manusia)
\end{abstract}

Kata Kunci Pengembangan, Kinerja, Pegawai

\begin{abstract}
This research aims to know the influence of Human Resources Development to Employee Performance in Kantor Inspektorat Kabupaten Mandailing Natal. This research is important because employee performance has significant role to do all organization activities. Human resources development will increase the employee performance.

This is a quantitative research and use simple regression technique. This research use questionnaire with 43 employee as samples and data processing with Softwere SPSS.

From this research the researcher know that Human Resources Development has positive and significant influence to Employee Performance in Kantor Inspektorat Kabupaten Mandailing Natal. The contribute of Human Resources Development to Employee Performance is $15,3 \%$ and $84,7 \%$ explained by others variables. The regression equation is Employee Performance $=55,873+0,324$ (Human Resources Development).
\end{abstract}

Key words Development, Performance, Human Resource

\section{I.PENDAHULUAN}

Sumber Daya Manusia (SDM) merupakan aset penting untuk menunjang keberhasilan suatu organisasi.Sumber daya manusia adalah pelaksana seluruh kebijakan organisasi sehingga perlu dibekali 
dengan pengetahuan yang memadai. Pentingnya sumber daya manusia ini perlu disadari oleh semua tingkatan manajemen baik di perusahaan maupun instansi pemerintah. Bagaimanapun majunya teknologi saat ini, namun faktor manusia tetap memegang peranan penting bagi keberhasilan suatu organisasi.

Banyak usaha yang dilakukan untuk meningkatkan kinerja sumber daya manusia, diantaranya pengembangan sumber daya manusia dengan memberikan kegiatan pendidikan dan pelatihan. Kegiatan pendidikan dan pelatihan merupakan suatu proses dengan memberikan atau meningkatkan kemampuan dan keterampilan serta menanamkan sikap baik kepada pegawai dimana proses tersebut akan sangat membantu pegawai dalam mengoreksi kekurangan-kekurangan kerjanya di masa silam sehingga pegawai tersebut dapat meningkatkan kinerjanya.

Pada instansi pemerintah peranan sumber daya manusia atau pegawai dalam melaksanakan program-program pemerintah sangat penting. Pegawai atau aparatur sipil negara yang profesional dan berkinerja tinggi akan mendukung tercapainya tujuan pembangunan nasional melalui program-program yang ditetapkan pemerintah. Demikian juga halnya dengan Kantor Inspektorat Kabupaten Mandailing Natal sebagai instansi pemerintah yang bertugas melaksanakan pengawasan penyelenggaraan pemerintahan daerah khususnya di lingkungan Pemerintah Kabupaten Mandailing Natal, tentunya memerlukan sumber daya manusia yang profesional dan berkinerja tinggi dalam pencapaian tujuannya secara efektif dan efisien.

Sesuai dengan tuntutan nasional dan global untuk mewujudkan kepemerintahan yang baik diperlukan pegawai yang mempunyai kompetensi jabatan dalam penyelenggaraan pemerintah dan pembangunan. Untuk memperoleh kompetensi dilakukan peningkatan kualitas kemampuan profesional, sikap pengabdian dan kesetiaan pada perjuangan bangsa dan negara, semangat persatuan dan kesatuan bangsa, serta pengembangan wawasan pegawai negeri sipil. Dalam rangka itu diselenggarakan kegiatan pendidikan dan pelatihan sebagai bagian yang tidak terpisahkan dari pengembangan pegawai secara umum dan khususnya pegawai negeri sipil yang ada di lingkungan Kantor Inspektorat Kabupaten Mandailing Natal. Pengembangan pegawai yang dimaksud antara lain mengikutsertakan pegawainya untuk mengikuti pendidikan dan pelatihan struktural seperti diklat prajabatan, diklat dalam jabatan dan diklat fungsional serta diklat teknis di berbagai bidang.

Selain dari itu seluruh pegawai negeri sipil di lingkungan Kantor Inspektorat Kabupaten Mandailing Natal juga mendapatkan pendidikan dan pelatihan dasar yang merupakan program dari pemerintahan pusat berisi materi umum yang berkaitan dengan disiplin, etika, dan budaya kerja serta prinsip-prinsip kepegawaian. Fakta di atas menunjukkan bahwa Inspektorat mendukung penuh upaya peningkatan kinerja pegawai negeri sipilnya dalam rangka pencapaian visi dan misi organisasi.

Namun setelah melakukan observasi awal di Kantor Inspektorat Kabupaten Mandailing Natal, peneliti menemukan masih terdapat beberapa kelemahan yaitu:

1. SDM yang terlatih di bidang pengawasan masih belum mencukupi.

2. Penyelesaian Laporan Hasil Pemeriksaan (LHP) tidak tepat waktu.

3. Jumlah tenaga ahli bidang tertentu belum terpenuhi.

Tabel berikut menggambarkan capaian kinerja di lingkungan Kantor Inspektorat Kabupaten Mandailing Natal pada tahun 2015:

Tabel. 1

Capaian Kinerja Organisasi

\begin{tabular}{|c|c|c|c|c|c|}
\hline \multirow{2}{*}{$\begin{array}{l}\mathbf{N} \\
\mathbf{O}\end{array}$} & $\begin{array}{l}\text { SASARAN } \\
\text { STRATEGIS }\end{array}$ & $\begin{array}{l}\text { INDIKATOR } \\
\text { KINERJA } \\
\end{array}$ & TARGET & $\begin{array}{l}\text { PROGRAM/KE- } \\
\text { GIATAN }\end{array}$ & $\begin{array}{l}\text { REALISASI } \\
\text { KINERJA }\end{array}$ \\
\hline & (1) & (2) & (3) & (4) & (5) \\
\hline 1 & $\begin{array}{l}\text { Meningkatnya } \\
\text { penyelesaian Tindak } \\
\text { Lanjut Hasil } \\
\text { Pemeriksaan Aparat } \\
\text { Pengawasan } \\
\text { Fungsional } \\
\text { Pemerintah Baik } \\
\text { Regional Maupun } \\
\text { Pusat }\end{array}$ & $\begin{array}{l}\text { Jumlah } \\
\text { Rekomendasi } \\
\text { dari Laporan } \\
\text { Hasil } \\
\text { Pemeriksaan } \\
\text { yang telah } \\
\text { ditindaklanjuti } \\
\text { dan telah } \\
\text { dinyatakan } \\
\text { selesai }\end{array}$ & $85 \%$ & $\begin{array}{l}\text { Pelaksanaan } \\
\text { Rapat Koordinasi } \\
\text { dan Konsultasi ke } \\
\text { luar Daerah }\end{array}$ & $75,42 \%$ \\
\hline 2 & $\begin{array}{l}\text { Meningkatnya } \\
\text { profesionalisme dan }\end{array}$ & $\begin{array}{l}\text { Bertambahnya } \\
\text { Tenaga }\end{array}$ & 7 Orang & $\begin{array}{l}\text { Pendidikan dan } \\
\text { Pelatihan Formal }\end{array}$ & $66,24 \%$ \\
\hline
\end{tabular}




\begin{tabular}{|l|l|l|l|l|}
\hline $\begin{array}{l}\text { kompetensi SDM } \\
\text { Inspektorat }\end{array}$ & $\begin{array}{l}\text { Pemeriksa } \\
\text { yang memiliki } \\
\text { Sertifikat }\end{array}$ & & & \\
\hline
\end{tabular}

Sumber : Capaian Kinerja Inspektorat Kabupaten Mandailing Natal Tahun 2015

Dari tabel diatas dapat disimpulkan bahwa kinerja Kantor Inspektorat Kabupaten Mandailing Natal Pada Tahun Anggaran 2015 pada beberapa aspek masih di bawah harapan. Capaian kinerja Inspektorat Kabupaten Mandailing Natal yang pencapaiannya masih rendah dapat mempengaruhi pencapaian visi dan misi Inspektorat Kabupaten Mandailing Natal. Hal ini perlu untuk dikaji lebih lanjut mengingat instansi ini secara rutin melaksanakan kegiatan pengembangan pegawainya. Hal inilah yang melatarbelakangi dilaksanakannya penelitian ini dengan judul "Pengaruh Pengembangan Terhadap Kinerja Pegawai Pada Kantor Inspektorat Kabupaten Mandailing Natal”.

\section{TINJAUAN PUSTAKA}

1. Kinerja Pegawai

\section{A. Pengertian Kinerja}

Pada umumnya kinerja diberi batasan sebagai kesuksesan seseorang di dalam melaksanakan suatu pekerjaan. Kinerja adalah istilah yang populer di dalam manajemen, yang mana istilah kinerja didefinisikan dengan istilah hasil kerja, prestasi kerja dan performance. Banyak pendapat para ahli tentang defenisi kinerja antara lain:

1) Dalam Kamus Bahasa Indonesia dikemukakan arti kinerja sebagai sesuatu yang dicapai, prestasi yang diperlihatkan dan kemampuan kerja".

2) Menurut Armstrong dan Baron seperti dikutip oleh Wibowo (2007:2) kinerja merupakan hasil pekerjaan yang mempunyai hubungan kuat dengan tujuan strategis organisasi, kepuasan konsumen dan memberikan kontribusi ekonomi.

3) Anwar Prabu Mangkunegara (2010:9) menyatakan bahwa kinerja karyawan adalah hasil kerja secara kualitas dan kuantitas yang dicapai oleh seseorang karyawan dalam melaksanakan tugasnya sesuai dengan tanggung jawab yang diberikan kepadanya.

4) Faustino Cardosa Gomes seperti dikutip oleh Anwar Prabu Mangkunegara (2010:9) mengemukakan defenisi kinerja karyawan sebagai ungkapan seperti output, efisiensi serta efektivitas sering dihubungkan dengan produktivitas.

5) Westra seperti dikutip oleh Endin Nasrudin (2010:239) mengemukakan bahwa kinerja (performance) adalah pelaksanaan tugas pekerjaan pada waktu tertentu.

Pengertian lainnya tentang kinerja dikemukakan oleh Prawirosentono seperti dikutip oleh Endin Nasrudin (2010:238) yang merujuk pada rumusan The Scribner-Bantam English Dictionary, bahwa kata performance berasal dari kata to perform, yang mempunyai entris sebagai berikut:

1) Melakukan, menjalankan, melaksanakan (to do or carry out, execute)

2) Memenuhi atau menjalankan kewajiban suatu nazar (to discharge or fulfill, as a now)

3) Menggambarkan suatu karakter dalam suatu permainan (to portray, as a character in a play)

4) Melaksanakan atau menyempurnakan tanggung jawab (to execute or complete an undertaking)

5) Melaksanakan suatu kegiatan dalam suatu permainan (to act a part in a play)

6) Melakukan sesuatu yang diharapkan oleh seseorang atau mesin (to do what is expected of a person or machine)

Lebih lanjut, Prawirosentono, menempatkan pengertian kinerja yang relevan dengan konsep manajemen sumber daya manusia, dalam arti to perform, berarti melakukan suatu kegiatan dan menyempurnakannya sesuai dengan tanggung jawabnya dengan hasil seperti yang diharapkan. Adapun kata performance sebagai kata benda (noun) adalah thing done, yang berarti suatu hasil yang telah dikerjakan.

Performance sering diartikan sebagai kinerja, hasil kerja atau prestasi kerja. Kinerja mempunyai makna yang lebih luas, bukan hanya menyatakan sebagai hasil kerja, tetapi juga bagaimana proses kerja berlangsung. Kinerja adalah tentang melakukan pekerjaan dan hasil yang dicapai dari pekerjaan tersebut. Kinerja adalah tentang apa yang dikerjakan dan bagaimana cara mengerjakannya.

Dari penjelasan di atas dapat disimpulkan bahwa kinerja adalah pencapaian hasil pekerjaan seseorang atas pekerjaan yang ditugaskan kepadanya dilihat dari keefektifan dan keefesienannya. Mangkunegara seperti yang dikutip oleh Endin Nasrudin (2010:240) mengemukakan bahwa ada dua faktor yang memengaruhi kinerja, yaitu faktor kemampuan (ability) dan faktor motivasi (motivation). 
Faktor kemampuan terdiri dari kemampuan potensi (IQ) dan kemampuan real (knowledge + skill). Artinya, seseorang yang memiliki IQ tinggi dan ditunjang dengan pendidikan yang memadai serta trampil dalam melaksanakan tugasnya, ia akan lebih mudah dalam mencapai kinerja yang diharapkan. Sementara faktor motivasi terbentuk dari sikap (attitude) seseorang dalam menghadapi situasi kerja. Motivasi merupakan kondisi yang menggerakkan diri seseorang agar terarah untuk mencapai tujuan kerja.

Menurut Ismet Huntua, ada tiga jenis kinerja dilihat dari manajemen umum kerja organisasi, yakni sebagai berikut:

1) Kinerja administratif adalah kinerja yang berkaitan dengan kinerja administrasi, seperti struktur organisasi, hubungan otoritas (wewenang) dan tanggung jawab, serta mekanisme aliran transformasi untuk tercapainya sinkronisasi antar unit kerja dalam organisasi.

2) Kinerja operasional adalah kinerja yang terkait dengan kegiatan operasional, seperti penyediaan seluruh fasilitas operasi dan pemeliharaan arus kegiatan agar seluruh tujuan organisasi dapat tercapai secara efektif dan efisien.

3) Kinerja strategik adalah kinerja yang terkait dengan pencapaian misi atau tujuan umum organisasi serta kebijakan strategis yang sangat berpengaruh terhadap kelangsungan hidup organisasi.

Mangkunegara (2010:22) menyatakan paling tidak terdapat tujuh langkah yang dapat dilakukan dalam rangka peningkatan kinerja, yaitu:

1) Mengetahui adanya kekurangan dalam kinerja.

2) Mengenali kekurangan/masalah dan tingkat keseriusan masalah.

3) Mengidentifikasi hal-hal yang mungkin menjadi penyebab masalah, baik yang berhubungan dengan sistem maupun yang berhubungan dengan pegawai itu sendiri.

4) Mengembangkan rencana tindakan untuk menanggulangi penyebab kekurangan/masalah tersebut.

5) Melakukan rencana tindakan tersebut.

6) Melakukan evaluasi apakah masalah tersebut sudah teratasi atau belum.

7) Mulai dari awal, apabila perlu.

Berdasarkan hasil penelitian David Mc. Clelland tentang pencapaian kinerja seperti dikutip Mangkunegara (2010:28), dapat disimpulkan bahwa individu-individu yang memiliki motivasi berprestasi tinggi untuk mencapai kinerja dapat dibedakan dengan yang lainnya dalam 4 (empat) ciri sebagai berikut:

1) Individu yang senang bekerja dan menghadapi tantangan yang moderat.

2) Individu yang memperoleh sedikit kepuasan jika pekerjaannya sangat mudah dan jika terlalu sulit cenderung kecewa.

3) Individu yang senang memperoleh umpan balik yang konkret mengenai keberhasilan pekerjaannya.

4) Individu yang cenderung tidak menyenangi tugas tersebut jika tidak mencapai prestasi sesuai dengan yang diinginkan.

5) Individu yang lebih senang bertanggung jawab secara personal atas tugas yang dikerjakan.

6) Individu yang puas dengan hasil bila pekerjaan dilakukan sendiri.

7) Individu yang cenderung inovatif.

8) Individu yang selalu mencari kemungkinan pekerjaan yang lebih menantang, meninggalkan sesuatu yang lama dan menjadi rutinitas serta berusaha untuk menemukan sesuatu yang baru.

Tinggi rendahnya kinerja pegawai tergantung kepada faktor-faktor yang mempengaruhinya. Dalam hal ini A. Dale Timple seperti dikutip Mangkunegara (2010:15) faktor-faktor kinerja terdiri dari faktor internal (faktor yang dihubungkan dengan sifat seseorang) dan faktor eksternal (faktor yang berasal dari lingkungan).

Menurut Mangkunegara (2010:13) faktor-faktor yang mempengaruhi kinerja seseorang ialah:

1) Faktor kemampuan, secara umum kemampuan ini terbadi menjadi dua yaitu kemampuan potensi (IQ) dan kemampuan reality (knowledge dan skill). Misalnya seorang dosen seharusnya memiliki kedua kemampuan tersebut agar dapat menyelesaikan jenjang pendidikan formal minimal S2 dan memiliki kemampuan mengajar dalam mata kuliah ampuannya.

2) Faktor motivasi, motivasi terbentuk dari sikap karyawan dala menghadapi situasi kerja. Misalnya motivasi bagi seorang dosen sangat penting untuk mencapai visi dan misi institusi pendidikan. Menjadi dosen hendaknya merupakan motivasi yang terbentuk dari awal (by plan), bukan karena keterpaksaan atau kebetulan (by accident).

\section{B. Kinerja dalam pandangan Islam}


Islam adalah ajaran yang komprehensif dan universal. Islam memberikan petunjuk bagi manusia bagaimana seharusnya berlaku dan bertindak dalam menjalani kehidupannya untuk mencapai keselamatan di dunia dan akhirat. Islam menganjurkan umatnya untuk bekerja keras untuk memperoleh kemakmuran di dunia tanpa melupakan kewajibannya sebagai hamba-Nya.

Islam mengajarkan kepada umatnya bahwa bekerja adalah bagian dari ibadah. Islam juga menganjurkan umatnya agar bekerja dengan sungguh-sungguh untuk memperoleh hasil yang terbaik. Banyak ayat Al Qur'an yang secara tegas menjelaskan hal ini. Allah SWT berfirman dalam surat AlQashash ayat 77 sebagai berikut:

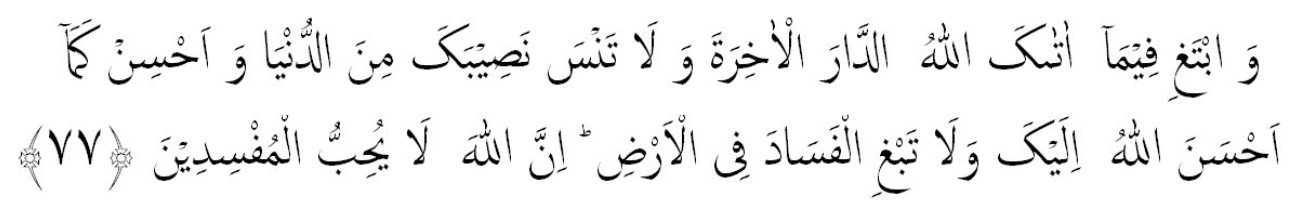

Artinya: Dan carilah pada apa yang telah dianugerahkan Allah kepadamu (kebahagiaan) negeri akhirat, dan janganlah kamu melupakan bagianmu dari (kenikmatan) duniawi dan berbuat baiklah (kepada orang lain) sebagaimana Allah telah berbuat baik kepadamu, dan janganlah kamu berbuat kerusakan di (muka) bumi. Sesungguhnya Allah tidak menyukai orang-orang yang berbuat kerusakan.

Ayat tersebut menjelaskan bahwa manusia diperintahkan untuk selalu berbuat baik, artinya manusia berkewajiban untuk selalu bekerja dan berbuat baik sehingga memperoleh hasil yang baik pula. Seorang pegawai/karyawan yang bekerja pada suatu instansi berkewajiban untuk bekerja dengan sebaikbaiknya karena bekerja adalah ibadah. Dengan bekerja dengan baik maka ia akan memperoleh imbalan yang baik pula berupa kemakmuran di dunia dan Allah akan mengganjarnya juga dengan kebahagiaan di akhirat berupa surga.

\section{Manajemen Kinerja}

Ada banyak defenisi manajemen kinerja yang dikemukakan oleh para ahli manajemen. Setiap defenisi tersebut memiliki kelebihan dan kekurangannya masing-masing, dalam pengertian cocok diterapkan di suatu perusahaan/organisasi dengan budaya organisasi tertentu, tetapi belum tentu tepat diterapkan pada perusahaan/organisasi lain dengan budaya organisasi yang berbeda. Fahmi (2012:226) menyatakan manajemen kinerja adalah suatu ilmu yang memadukan seni di dalamnya untuk menerapkan suatu konsep manajemen yang memiliki tingkat fleksibilitas yang representatif dan aspiratif guna mewujudkan visi dan misi perusahaan dengan cara mempergunakan orang yang ada di organisasi tersebut secara maksimal.

Suatu organisasi yang profesional tidak akan mampu mewujudkan suatu manajemen kinerja yang baik tanpa ada dukungan yang kuat dari seluruh komponen manajemen perusahaan dan juga tentunya para pemegang saham. Manajemen kinerja akan dapat diwujudkan jika ada hubungan dan keinginan yang sinergis antara atasan dan bawahan. Oleh karena itu salah satu dasar mewujudkan konsep manajemen kinerja adalah dengan mengembangkan dan mengedepankan komunikasi yang efektif antar berbagai pihak baik di lingkungan internal maupun eksternal perusahaan.

Seorang pebisnis dan investor khususnya sangat membutuhkan informasi tentang kondisi perusahaan tempat ia akan menginvestasikan dananya, karena sudah menjadi karakteristik dasar seorang investor dimana ia akan menempatkan dana yang dimilikinya pada tempat yang memiliki sisi profitable yang aman dan pasti. Oleh karena itu, bagi seorang investor ia menginginkan berbagai informasi yang maksimal tentang suatu perusahaan termasuk informasi tentang kualitas manajemen kinerja yang dimiliki oleh perusahaan tersebut. Hasil dan kualitas prestasi kerja yang maksimal tidak dapat dilepaskan dari hasil yang dibangun oleh pihak manajemen perusahaan karena tidak mungkin suatu prestasi kerja yang bagus itu bisa diperoleh tanpa ada penanganan yang serius dan mendalam dari pihak manajemen perusahaan.

Kegiatan manajemen kinerja harus melibatkan karyawan. Dengan kata lain karyawan merupakan bagian penting, penentu, dan pencipta manajemen kinerja yang diharapkan. Ada beberapa faktor yang mendasari seorang karyawan berkeinginan terlibat secara serius dalam usaha meningkatkan prestasi kerja perusahaan, yaitu:

1)Karyawan tersebut merasa perusahaan telah menjalankan peraturan dan ketentuan yang sesuai dengan yang mereka harapkan.

2)Karyawan merasa dirinya bukan hanya sekedar pekerja namun lebih dari itu, yaitu ia juga merasa dirinya sebagai bagian penting dari manajemen perusahaan. 
3)Tindakan dan prestasi karyawan selalu dihargai baik secara materi maupun non materi.

4)Pihak manajemen perusahaan dalam memposisikan karyawan tidak dalam konteks hubungan antara atasan dan bawahan, namun bersifat kekeluargaan.

5)Karyawan merasa perusahaan tempat ia bekerja bisa dijadikan sebagai tempat untuk menggantungkan hidupnya hingga hari tua.

\section{Pengembangan Sumber Daya Manusia}

\section{A.Pengertian Pengembangan}

Hasibuan (2011:22) menyatakan bahwa pengembangan (development) adalah proses peningkatan keterampilan teknis teoritis, konseptual, dan moral karyawan melalui pendidikan dan pelatihan. Pendidikan dan pelatihan yang diberikan harus sesuai dengan kebutuhan pekerjaan masa kini. Pengembangan bersifat lebih luas karena menyangkut banyak aspek seperti peningkatan dalam ke ilmuan, pengetahuan, kemampuan sikap dan kepribadian. Tokoh lain yaitu Husein Umar (1997:165) menyatakan pengembangan bertujuan antara lain untuk menutupi gap antara kecakapan karyawan dan permintaan jabatan, selain untuk meningkatkan efisiensi dan efektifitas kerja karyawan dalam mencapai sasaran kerja. Rachmawati (2008:15) menyatakan bahwa program pengembangan mengajarkan berbagai keterampilan baru kepada para karyawan agar mereka tidak menjadi usang dan untuk memenuhi keinginan karir mereka akibat perubahan lingkungan kerja.Kemudian dilakukan penilaian prestasi kerja yang bertujuan untuk melihat kinerja pegawai apakah sudah sesuai dengan yang diharapkan.

Setiap organisasi apapun bentuknya senantiasa akan berupaya untuk mencapai tujuan organisasi yang bersangkutan dengan efektif dan efisien. Martoyo (2000:61) menyatakan bahwa efisiensi maupun efektivitas organisasi sangat bergantung pada baik buruknya pengembangan sumber daya manusia/anggota organisasi itu sendiri. Ini berarti bahwa sumber daya manusia yang ada dalam organisasi tersebut secara proporsional harus diberikan latihan dan pendidikan yang sebaik-baiknya, bahkan harus sesempurna mungkin. Latihan dan pendidikan ini dilaksanakan baik untuk karyawan baru (agar dapat menjalankan tugas-tugas baru yang dibebankan) maupun untuk karyawan lama (guna meningkatkan mutu pelaksanaan tugasnya sekarang maupun masa yang akan datang). Dengan demikian jelaslah bahwa program pengembangan ( latihan dan pendidikan) karyawan dalam organisasi sangat penting artinya dalam rangka memajukan organisasi yang bersangkutan, terlebih apabila pengetahuan dan teknologi makin berkembang dengan pesat.

Jenis pengembangan dikelompokkan atas pengembangan secara informal dan pengembangan secara formal.

1) Pengembangan secara informal yaitu atas keinginan dan usaha sendiri melatih dan mengembangkan dirinya dengan mempelajari buku-buku literatur yang ada hubungannya dengan pekerjaan atau jabatan, pengembangan secara informal menunjukan bahwa karyawan tersebut berkeinginan keras untuk maju dengan cara meningkatkan kemampuan kerjanya. Hal ini bermanfaat bagi perusahaan karena prestasi karyawan semakin besar disamping efisiensi dan produktivitasnya juga semakin baik.

2) Pengembangan secara formal yaitu karyawan ditugaskan perusahaan untuk mengikuti pendidikan dan pelatihan, baik yang dilakukan perusahaan maupun yang dilaksanakan lembaga-lambaga pendidikan atau pelatihan. Pengembangan secara formal dilakukan perusahaan karena tuntutan pekerjaan saat ini ataupun masa mendatang yang sifatnya nonkarier atau peningkatan karier seorang karyawan.

\section{B.Pengertian Sumber Daya Manusia}

Semula SDM merupakan terjemahan dari "human resources", namun, ada ahli yang menyamakan sumber daya manusia dengan "manpower" (tenaga kerja). Bahkan sebagian orang menyetarakan pengertian sumber daya manusia dengan personal (personalia, kepegawaian dan sebagainya).

Sumber daya manusia merupakan satu-satunya sumber daya yang memiliki akal perasaan, keinginan, keterampilan, pengetahuan,dorongan, daya, dan karya (rasio, rasa, dan karsa). Semua potensi sumber daya manusia tersebut berpengaruh terhadap upaya organisasi dalam mencapi tujuan. Betapapun majunya teknologi, perkembangan informasi, tersedianya modal dan memadainya bahan, jika tanpa sumber daya manusia sulit bagi organisasi itu untuk mencapai tujuan.

Menurut Werther dan Davis seperti dikutip oleh Sutrisno (2011:3) sumber daya manusia adalah pegawai yang siap, mampu, dan siaga dalam mencapi tujuan-tujuan organisasi. Sebagaimana dikemukakan bahwa dimensi pokok sisi sumber daya adalah kontribusinya terhadap organisasi sedangkan dimensi pokok manusia adalah perlakuan kontribusi terhadapnya yang pada gilirannya akan menentukan 
kualitas dan kapabilitas hidupnya. Sedangkan sumber daya manusia berkualitas tinggi menurut Ndraha adalah sumber daya manusia yang mampu menciptakan bukan saja nilai komparatif tetapi juga nilai kompetitif, generative, inovatif dengan mengunakan energi tertinggi seperti: Intelligence,creativity, dan imagination; tidak lagi semata-mata menggunakan energi kasar, seperti bahan mentah, lahan, air, tenaga otot dan sebagainya.

\section{C.Pengembangan Sumber Daya Manusia}

Persoalan kebutuhan memperoleh sumber daya manusia unggul dan professional yang diharapkan oleh banyak organisasi atau perusahaan di Indonesia untuk bisa bersaing dalam era globalisasi sering kali hanya menjadi angan-angan semata. Begitu banyak dana pengembangan sumber daya manusia dikeluarkan dengan maksud tersebut. Proses pengembangan sumber daya manusia merupakan starting point dimana organisasi ingin meningkatkan dan mengembangkan skills, knowledge, dan ability individu sesuai dengan kebutuhan masa kini maupun masa mendatang.

Berbicara masalah pengembangan sumber daya manusia sebenarnya dapat dilihat dari dua aspek, yaitu kuantitas dan kualitas.Pengertian kuantitas menyangkut jumlah sumber daya manusia. Kuantitas sumber daya manusia tanpa disertai dengan kualitas sumber daya manusia yang baik akan menjadi beban suatu perusahaan.

Handoko (2001:117) menyatakan bahwa pengembangan sumber daya manusia juga merupakan suatu cara efektif untuk menghadapi beberapa tantangan yang banyak dihadapi organisasi besar. Oleh karena itu, program pengembangan karyawan hendaknya disusun secara cermat dan didasarkan kepada metode-metode ilmiah serta berpedoman pada keterampilan yang dibutuhkan perusahaan saat ini maupun masa depan. Pengembangan harus bertujuan untuk meningkatkan kemampuan teknis teoritis, konseptual, dan moral karyawan, supaya prestasi kerjanya baik dan mencapai hasil yang optimal.

Pengembangan sumber daya manusia adalah program yang khusus dirancang suatu organisasi dengan tujuan membantu karyawan dalam meningkatkan kemampuan, pengetahuan dan memperbaiki sikapnya. Berbagai aktivitas yang dapat dilakukan oleh suatu organisasi dalam usaha pengembangan tenaga kerja, antara lain adalah latihan, pendidikan, rotasi jabatan, promosi dan pemindahan.

Dalam konteks sumber daya manusia, pengembangan dipandang sebagai peningkatan kualitas sumber daya manusia melalui program pelatihan, pendidikan.Apa yang dapat dijelaskan dari pengembangan sumber daya manusia adalah tentang developmental practice dan membutuhkan kolaborasi dengan program-program manajemen sumber daya manusia untuk mencapai hasil yang diinginkan.

Pengembangan sumber daya manusia tujuannya untuk meningkatkan kualitas profesionalisme dan keterampilan para karyawan dalam melaksanakan tugas dan fungsinya secara optimal.Dengan mengembangkan kecakapan karyawan dimaksudkan sebagai setiap usaha dari pimpinan untuk menambah keahlian kerja tiap karyawan sehingga di dalam melaksanakan tugas-tugasnya dapat lebih efisien dan produktif.Oleh karena itu, organisasi perlu terus melakukan pengembangan sumber daya manusia, karena investasi di dalam pengembangan merupakan pengeluaran yang ditujukan untuk memperbaiki kapasitas produktif dari manusia.

\section{METODOLOGI PENELITIAN}

Berdasarkan analisisnya penelitian ini adalah penelitian kuantitatif. Menurut Sujarweni (2015:12) penelitian kuantitatif adalah jenis penelitian yang menghasilkan penemuan-penemuan yang dapat dicapai (diperoleh) dengan menggunakan prosedur-prosedur statistik atau cara-cara lain dari kuantifikasi (pengukuran). Pendekatan kuantitatif memusatkan perhatian pada gejala-gejala yang mempunyai karakteristik tertentu di dalam kehidupan manusia yang disebut variabel.

Adapun populasi dalam penelitian ini adalah seluruh pegawai Inspektorat Kabupaten Mandailing Natal yang berjumlah 43 orang. Populasi dalam penelitian ini hanya pegawai yang berstatus PNS yang telah pernah mengikuti pengembangan sumber daya manusia. Sesuai dengan pendapat Arikunto (1993:107) yang menyatakan apabila subyeknya kurang dari 100, lebih baik diambil semua sehingga penelitiannya merupakan penelitian populasi maka keseluruhan pegawai Inspektorat Kabupaten Mandailing Natal yang berjumlah 43 orang sekaligus juga sebagai sampel dalam penelitian ini.

Instrumen penelitian ini adalah menggunakan angket sebanyak 24 butir untuk variabel pengembangan sumber daya manusia (X) dan 20 butir untuk variabel kinerja pegawai (Y). Pernyataan angket diturunkan dari indikator-indikator variabel seperti pada tabel berikut:

Tabel. 2

Indikator Pengembangan Sumber Daya Manusia 


\begin{tabular}{|c|c|c|}
\hline Variabel & Indikator & Nomor Soal \\
\hline \multirow{5}{*}{$\begin{array}{l}\text { Pengembangan } \\
\text { Sumber Daya } \\
\text { Manusia (X) }\end{array}$} & 1. Peserta & $1,2,3,4,5,6$ \\
\hline & 2. Kurikulum & $7,8,9,10$ \\
\hline & 3. Sarana & $11,12,13,14,15,16$ \\
\hline & 4. Pelatih & $17,18,19,20,21,22$ \\
\hline & 5. Sasaran & 23,24 \\
\hline
\end{tabular}

Tabel. 3

Indikator Kinerja Pegawai

\begin{tabular}{|l|ll|l|}
\hline \multicolumn{1}{|c|}{ Variabel } & \multicolumn{1}{|c|}{ Indikator } & \multicolumn{1}{c|}{ Nomor Soal } \\
\hline \multirow{2}{*}{$\begin{array}{l}\text { Kinerja Pegawai } \\
(\mathrm{X})\end{array}$} & 1. & Efektivitas dan Efisiensi & $1,2,3,4,5,6$ \\
\cline { 2 - 4 } & 2. & Otoritas (tanggung jawab) & $7,8,9,10,11$ \\
\cline { 2 - 4 } & 3. & Disiplin & $12,13,14$ \\
\cline { 2 - 4 } & 4. & Inisiatif & $15,16,17,18,19,20$ \\
\hline
\end{tabular}

Bentuk angket yang digunakan adalah angket tertutup yaitu responden memilih jawaban yang telah disediakan sesuai dengan keadaan dirinya.Skala yang digunakan adalah skala likert, skala likert adalah skala yang berisi lima tingkat jawaban yang merupakan skala jenis ordinal. Dimana skala likert ini merupakan cara yang paling sering digunakan dalam menentukan skor. Angket ini menggunakan skala likert yaitu sebagai berikut :

Tabel 4

Skala Likert

\begin{tabular}{|c|c|}
\hline Kategori & Bobot \\
\hline Sangat Setuju & 5 \\
\hline Setuju & 4 \\
\hline Kurang Setuju & 3 \\
\hline Tidak Setuju & 2 \\
\hline Sangat Tidak Setuju & 1 \\
\hline
\end{tabular}

\section{HASIL PENELITIAN}

\section{Uji Instrumen}

Berdasarkan uji validitas instrumen yang telah dilakukan ternyata butir angket nomor 11, 12, 19, dan 20 untuk variabel pengembangan sumber daya manusia (X) tidak valid sehingga tersisa sebanyak 20 butir angket untuk dilanjutkan pada tahap uji reliabilitas. Dari uji reliabilitas yang dilakukan diketahui bahwa 20 butir angket tersebut reliabel.

Selanjutnya berdasarkan uji validitas instrumen yang telah dilakukan ternyata butir angket nomor 15 untuk variabel kinerja pegawai (Y) tidak valid sehingga tersisa sebanyak 19 butir angket untuk dilanjutkan pada tahap uji reliabilitas. Dari uji reliabilitas yang dilakukan diketahui bahwa 19 butir angket tersebut reliabel.

2. Uji Prasyarat

Teknik uji normalitas yang digunakan adalah Kolmogorov-Smirnov, dengan bantuan software SPSS diperoleh tabel berikut:

Tabel 5

Hasil Uji Kolmogorov Smirnov

One-Sample Kolmogorov-Smirnov Test

\begin{tabular}{|ll|r|r|}
\hline & & $\begin{array}{c}\text { Pengembangan } \\
\text { Sumber Daya } \\
\text { Manusia }\end{array}$ & Kinerja Pegawai \\
\hline $\mathrm{N}$ & Mean & 43 & 43 \\
Normal & 87.2558 & 83.1860 \\
Parameters & St, & 8.87772 & 7.64154 \\
Most Extreme & Absolute & .125 & .109 \\
Differences & Positive & .116 & .078 \\
& Negative & -.125 & -.109 \\
Test Statistic & & .125 & .109
\end{tabular}




\begin{tabular}{|l|r|r|}
\hline Asymp. Sig. (2-tailed) & $.089^{\mathrm{c}}$ & $.200^{\mathrm{c}, \mathrm{d}}$ \\
\hline
\end{tabular}

a. Test distribution is Normal.

b. Calculated from data.

c. Lilliefors Significance Correction.

d. This is a lower bound of the true significance.

Berdasarkan tebel di atas terlihat nilai signifikansi sebesar 0,089 untuk variabel Pengembangan sumber daya manusia dan 0,200 untuk variabel Kinerja pegawai. Nilai tersebut lebih besar dari nilai signifikan 0,05. Jadi dapat disimpulkan bahwa data terdistribusi normal.

Selanjutnya dari uji linieritas yang dilakukan diperoleh tabel berikut:

Tabel. 6

Hasil Uji Linieritas

ANOVA Table

\begin{tabular}{|c|c|c|c|c|c|c|c|}
\hline & & & $\begin{array}{l}\text { Sum of } \\
\text { Squares }\end{array}$ & Df & Mean Square & $\mathrm{F}$ & Sig. \\
\hline \multirow{5}{*}{$\begin{array}{l}\text { kinerjapeg } \\
\text { awai * } \\
\text { pengemba } \\
\text { ngansumb } \\
\text { erdayaman } \\
\text { usia }\end{array}$} & Between & (Combined) & 1238.462 & 18 & 68.803 & 1.360 & .238 \\
\hline & Groups & Linearity & 385.717 & 1 & 385.717 & 7.625 & .011 \\
\hline & & $\begin{array}{l}\text { Deviation from } \\
\text { Linearity }\end{array}$ & 852.745 & 17 & 50.161 & .992 & .497 \\
\hline & \multicolumn{2}{|c|}{ Within Groups } & 1214.050 & 24 & 50.585 & & \\
\hline & \multicolumn{2}{|l|}{ Total } & 2452.512 & 42 & & & \\
\hline
\end{tabular}

Dari output di atas dapat diketahui bahwa signifikansi pada Linearity adalah sebesar 0,011. Karena signifikansi kurang dari 0,05 maka dapat disimpulkan bahwa antara variabel pengembangan sumber daya manusia dan kinerja pegawai terdapat hubungan yang linear.

\section{Uji Koefisien Korelasi (r)}

Dari output SPSS diperoleh tabel berikut:

Tabel. 7

Hasil Uji Koefisien Korelasi

\begin{tabular}{|l|r|r|r|c|}
\hline Model & $\mathrm{R}$ & R Square & $\begin{array}{c}\text { Adjusted R } \\
\text { Square }\end{array}$ & $\begin{array}{c}\text { Std. Error of the } \\
\text { Estimate }\end{array}$ \\
\hline 1 &, $391^{\mathrm{a}}$ &, 153 &, 132 & 6,861 \\
\hline
\end{tabular}

Nilai koefisien korelasi (r) adalah sebesar 0,391. Artinya antara variabel pengembangan sumber daya manusia(X) dengan kinerja pegawai $(\mathrm{Y})$ memiliki hubungan yang rendah. Hal ini sesuai dengan pendapat Kuswanto (2012:90) yang menyatakan bahwa nilai $r$ dalam rentang 0,20-0,399 menunjukkan tingkat hubungan yang rendah.

4. Uji Koefisien Determinasi

Dari output SPSS diperoleh tabel berikut:

Tabel. 8

\section{Hasil Uji Koefisien Determinasi}

\begin{tabular}{|l|r|r|r|c|}
\hline Model & $\mathrm{R}$ & R Square & $\begin{array}{c}\text { Adjusted R } \\
\text { Square }\end{array}$ & $\begin{array}{c}\text { Std. Error of the } \\
\text { Estimate }\end{array}$ \\
\hline 1 &, $391^{\mathrm{a}}$ &, 153 &, 132 & 6,861 \\
\hline
\end{tabular}

Nilai koefisien determinasi adalah sebesar 0,153. Hal ini menjelaskan bahwa variabel pengembangan sumber daya manusia $(\mathrm{X})$ hanya memberikan pengaruh $15,3 \%$ terhadap kinerja pegawai (Y) sedangkan sisanya $84,7 \%$ dipengaruhi oleh variabel lain yang tidak diteliti dalam penelitian ini.

\section{Persamaan Regresi}


Dalam penelitian ini dilakukan perhitungan persamaan regresi linier sederhana untuk mengetahui hubungan fungsional antara variabel pengembangan sumber daya manusia(X) dengan kinerja pegawai (Y) pada Kantor Inspektorat Kabupaten Mandailing Natal.

\section{Tabel. 9}

Hasil Uji Regresi Linear Sederhana Coefficients $^{\mathrm{a}}$

\begin{tabular}{|c|c|c|c|c|c|c|}
\hline \multirow{2}{*}{\multicolumn{2}{|c|}{ Model }} & \multicolumn{2}{|c|}{$\begin{array}{c}\text { Unstandardized } \\
\text { Coefficients }\end{array}$} & $\begin{array}{l}\text { Standardized } \\
\text { Coefficients }\end{array}$ & \multirow[b]{2}{*}{$\mathrm{t}$} & \multirow[b]{2}{*}{ Sig. } \\
\hline & & B & Std. Error & Beta & & \\
\hline \multirow[t]{2}{*}{1} & (Constant) & 55,873 & 10,458 & & 5,343 &, 000 \\
\hline & $\begin{array}{l}\text { Sumber_daya } \\
\text { manusia }\end{array}$ & ,324 & , 119 & ,391 & 2,719 & ,010 \\
\hline
\end{tabular}

a. Dependent Variable: Kinerja_Pegawai

Dari analisis menggunakan SPSS, diketahui bahwa nilai konstanta adalah 55,873 dan koefisien variabel pengembangan sumber daya manusia adalah 0,324. Sehingga persamaan regresinya adalah:

Kinerja pegawai $=55,873+0,324$ (Pengembangan sumber daya manusia)

Dari persamaan di atas dapat disimpulkan bahwa:

a. Konstanta sebesar 55,873 artinya apabila variabel pengembangan sumber daya manusia ditiadakan atau nol maka kinerja pegawai adalah sebesar 55,873 satuan.

b. Koefisien variabel pengembangan sumber daya manusia 0,324 artinya apabila varibel pengembangan sumber daya manusia dinaikkan 1 satuan maka kinerja pegawai akan meningkat sebesar 0,324 satuan.

6. Uji t

Uji $\mathrm{t}$ digunakan untuk mengetahui apakah variabel pengembangan sumber daya manusia(X) berpengaruh signifikan terhadap kinerja pegawai (Y) pada Kantor Inspektorat Kabupaten Mandailing Natal.

Berdasarkan Tabel 9 di atas diperoleh $t_{\text {hitung }}$ untuk variabel pengembangan sumber daya manusia (X) sebesar 2,719. Sementara $t_{\text {tabel }}$ yang diperoleh pada taraf signifikansi 5\% $(0,05)$ dengan nilai $\mathrm{dk}=\mathrm{N}-2$ atau $\mathrm{dk}=43-2=41$ adalah 1,68288. Karena $\mathrm{t}$ hitung $>\mathrm{t}$ tabel $(2,719>1,68288)$ maka Ho ditolak. Artinya dapat disimpulkan bahwa ada pengaruh yang positif signifikan antara variable pengembangan sumber daya manusia (X) terhadap kinerja pegawai (Y) pada Kantor Inspektorat Kabupaten Mandailing Natal.

\section{Pembahasan}

Dari hasil pengolahan data yang dilakukan menunjukkan adanya hubungan yang rendah antara pengembangan sumber daya manusia (X) terhadap kinerja pegawai $(\mathrm{Y})$. Hal ini ditunjukkan oleh nilai $\mathrm{r}$ sebesar 0,391 . Hal ini mengindikasikan adanya hubungan pengembangan sumber daya manusia (X) terhadap kinerja pegawai $(\mathrm{Y})$, namun kontribusi pengembangan sumber daya manusia hanya sebagian kecil dari beberapa variabel yang dapat mempengaruhi kinerja pegawai (Y). Masih banyak faktor lain yang mempengaruhi kinerja pegawai antara lain: kompensasi, gaya kepemimpinan, iklim kerja, motivasi, dan budaya organisasi.

Kemudian dari uji regresi linier sederhana diperoleh persamaan sebagai berikut:

\section{Kinerja Pegawai $=55,873$ + 0,324 (Pengembangan Sumber Daya Manusia)}

Dari persamaan di atas terlihat bahwa koefisien variabel Pengembangan Sumber Daya Manusia bernilai positif $(+)$. Hal ini menunjukkan adanya hubungan yang positif atau searah antara variabel pengembangan sumber daya manusia dan kinerja pegawai. Dengan begitu setiap usaha meningkatkan pengembangan sumber daya manusia maka akan meningkatkan kinerja pegawai pada Kantor Inspektorat Kabupaten Mandailing Natal.

Berdasarkan uji t yang dilakukan hasilnya menunjukkan bahwa pengembangan sumber daya manusia berpengaruh terhadap kinerja pegawai. Hasil penelitian ini menyatakan bahwa pengembangan sumber daya manusia yang baik akan meningkatkan kinerja pegawai. 
Berdasarkan perhitungan Koefisien Determinasi ( $\mathrm{r}$ square) yang dilakukan diperoleh nilai koefisien determinasi sebesar 0,153. Artinya variabel pengembangan sumber daya manusia (X) memberikan pengaruh sebesar 15,3\% terhadap kinerja pegawai (Y). Walaupun memberikan pengaruh kecil namun faktor pengembangan sumber daya manusia ini tetap perlu diperhatikan dan ditingkatkan oleh pihak Inspektorat Kabupaten Mandailing Natal demi meningkatkan kinerja pegawai di masa yang akan datang. Hasil penelitian ini sesuai dengan teori pengembangan sumber daya manusia yang bertujuan ingin meningkatkan dan mengembangkan skills, knowledge, dan ability individu sesuai dengan kebutuhan masa kini maupun masa mendatang .

\section{KESIMPULAN}

Dari hasil penelitian yang telah dilakukan disimpulkan bahwa pengembangan sumber daya manusia berpengaruh positif terhadap kinerja pegawai pada Kantor Inspektorat Kabupaten Mandailing Natal. Besarnya kontribusi variabel pengembangan sumber daya manusia terhadap kinerja pegawai pada Kantor Inspektorat Kabupaten Mandailing Natal adalah sebesar 15,3\%, sedangkan sisanya $84,7 \%$ dipengaruhi oleh variabel lain yang tidak diteliti dalam penelitian ini.

\section{DAFTAR PUSTAKA}

Arikunto, Suharsimi (1993). Prosedur Statistik, Jakarta: PT. Rineka Cipta.

Fahmi, Irham (2012), Manajemen,Teori, Kasus, dan Solusi, Bandung: CV. AlfaBeta.

Handoko, Hani T. (2001), Manajemen Personalia dan Sumber Daya Manusia,Yogyakarta: BPFE.

Hasibuan, Malayu S. P. (2011). Manajemen Sumber Daya Manusia, Jakarta : PT. Bumi Aksara.

Kuswanto, Dedy (2012), Statistik Untuk Pemula \& Orang Awam, Jakarta: Laskar Aksara.

Mangkunegara, AA. Anwar Prabu (2010). Evaluasi Kinerja SDM, Cetakan Kedua, Bandung: PT Refika Aditama.

Martoyo, Susilo (2000). Manajemen Sumber Daya Manusia, Yogyakarta: BPFE.

Nasrudin, Endin (2010), Psikologi Manajemen, Bandung: Pustaka Setia.

Rachmawati, Ike Kusdyah (2008). Manajemen Sumber Daya Manusia, Yogyakarta: C.VAndi Offset.

Sujarweni, V. Wiratna (2015). Metodologi Penelitian Bisnis, Yogyakarta: Pustaka Baru Press.

Sutrisno, Edy (2011), Manajemen Sumber Daya Manusia, Jakarta: Kencana Prenada Media.

Umar, Husein (1997). Studi Kelayakan Bisnis, cetakan, 1, Jakarta: Gramedia Pustaka Utama.

Wibowo (2007). Manajemen Kinerja, Jakarta: PT. Raja Grafindo Persada. 